CHAPTER 17

\title{
Muslim Responses to Missionary Literature in Egypt in the Late Nineteenth and Early Twentieth Centuries
}

\author{
Umar Ryad
}

\section{Introduction}

In the modern age, a number of studies have examined the historical development of Christian approaches to Islam. Also, the history of modern Christian missions has been written predominantly from a Christian missionary perspective. ${ }^{1}$ However, much work is needed on the views of Christianity held by members of other faiths, in particular by Muslims, and how these ideas and interpretations in turn changed and developed. ${ }^{2}$

Throughout the late nineteenth and early twentieth centuries, many western Christian missionaries travelled to Egypt and wrote and distributed printed

1 See for example Erich W. Bethmann, Bridge to Islam: A Study of the Religious Forces of Islam and Christianity in the Near East (London: George Allen \& Unwin Ltd, 1953); Kenneth Scott Latourette, A History of the Expansion of Christianity: The Great Century A.D. 1800-A.D. 1914 in Northern Africa and Asia, vols. 4-6 (London: Eyre and Spottiswoode, 1945), Julius Richter, A History of Protestant Missions in the Near East, 1st edition (New York: AMs Press, 1970, reprinted from the edition of 1910); Dennis H. Phillips, 'The American Missionary in Morocco', The Muslim World 65.1 (1975): 1-20; Lyle L. Vander Werff, Christian Mission to Muslims: the Record (South Pasadena, CA: William Carey Library, 1977).

2 Hugh Goddard, Muslim Perceptions of Christianity (London: Grey Seal, 1996), ix; cf. Mahmoud Ayoub, 'Islam and Christianity: A Study of Muhammad Abduh's View of the two Religions', Humaniora Islamica 2 (1974), 121-137; Mahmoud Ayoub, 'Muslim Views of Christianity: Some Modern Examples', Islamochristiana 10 (1984): 49-70; Mahmoud Ayoub, 'Roots of MuslimChristian Conflict', The Muslim World 79 (1989): 25-45: Christine Schirrmacher, Mit den Waffen des Gegners: Christlich-muslimische Kontroversen im 19 und 20 Jahrhundert (Berlin: Klaus Schwarz Verlag, 1992); Hugh Goddard, 'Christianity from the Muslim Perspective: Varieties and Changes,' in Islam and Christianity: Mutual Perceptions since the mid-2oth Century, ed. Jacques Waardenburg (Leuven: Peeters, 1998), 213-255; Christine Schirrmacher, 'The Influence of Higher Bible Criticism on Muslim Apologetics in the Nineteenth Century', in Muslim Perceptions of Other Religions: A Historical Survey, ed. Jacques Waardenburg (New York: Oxford University Press, 1999), 270-279.

(C) KONINKLIJKE BRILL NV, LEIDEN, 2015 | DOI: 10.1163/9789004297210_019 
materials on and against Islamic doctrines and norms. For example, the wellknown missionary from Cambridge Douglas M. Thornton (d. 1907) saw literature as the most important means for 'reaching the educated classes and semi-civilized lands, ${ }^{3}$ and several prominent missionaries wrote on Islamic themes, either in English or Arabic. Among them were the Anglican Canon William Temple Gairdner (d. 1928) ${ }^{4}$ and Samuel Marinus Zwemer (d. 1952), ${ }^{5}$ a well-known leader of the Presbyterian Church in the United States of America. Gairdner for his part stressed the importance of 'harnessing' the Arabic language, or even Christianizing it, to serve specific missionary literary tasks. For Gairdner, by so doing missionaries were supposed to use 'Islam's own weapon' against 'Islam's own bosom' ${ }^{6}$

In response to this missionary literature, Muslim apologists composed antiChristian writings drawing on classical Muslim polemics and the critical study of the Bible that had emerged in Europe in the nineteenth century. Modern Biblical criticism frequently touched upon the miracles reported in the Hebrew Bible and the New Testament, which were being discussed in European universities at the time. The formulations of Christology, the Trinity, the deity of Jesus Christ, and the resurrection all came into question, and their historicity was doubted. ${ }^{7}$ These critical questions were rapidly transferred to Muslim countries, especially after the famous debate between Karl Gottlieb Pfander (d. 1865), a member of the Basler Missionsgesellschaft (Basel Missionary Society), and the Indian Muslim theologian, Rahmatullah al-Kayranāwī (d. 1891). The debate took place in Agra in April 1854 between Pfander, supported by T.V. French, and al-Kayranāwī with the assistance of Dr. Wazīr Khān, a medical doctor who studied in England in the 1830s. During his stay in England, Wazīr

3 W.H.T. Gairdner, D.M. Thornton: A Study in Missionary Ideals and Methods (London: Hodder and Stoughton, 1908), 162.

4 See Constance E. Padwick, Temple Gairdner of Cairo (London: Society for Promoting Christian Knowledge, 1929); Michael Shelley, 'Temple Gairdner of Cairo Revisited', Islam and ChristianMuslim Relations 10 (October 1999): 261-278.

5 About his life, see Alfred DeWitt Mason and Frederick J. Barny, History of the Arabian Mission (New York: The Board of foreign missions, Reformed church in America, 1926); J. Christy Wilson, Apostle to Islam: A biography of Samuel M. Zwemer (Grand Rapids, MI: Baker Book House, 1952); J. Christy Wilson, 'The Epic of Samuel Zwemer', The Moslem World 57 (June 1967): 7993; J. Christy Wilson, Flaming Prophet: The Story of Samuel Zwemer (New York: Friendship Press, 1970); Vander Werff, Christian Mission, 224-267; Alan Neely, 'Zwemer, Samuel Marinus', in Biographical Dictionary of Christian Missions, ed. Gerald H. Anderson (New York: Macmillan Reference USA, 1998), 763 .

6 Gairdner, D.M. Thornton, 170.

7 Schirrmacher, 'The Influence of Higher Bible Criticism,' 274. 
Khān collected several works of biblical criticism by western scholars such as Thomas Hartwell Horne (d. 1862 $)^{8}$ and David Friedrich Strauss (d. 1874), ${ }^{9}$ and he began to study Greek and Hebrew. His 'knowledge of Christianity from western sources was to provide much of the material al-Kayranāwī needed for his counter-attack on missionaries'.10 According to Schirrmacher, al-Kayranāwī was the first apologist in the Muslim world who referred to biblical criticism and other Bible commentaries in order to fight back against Christianity with its own weapons. He used different works of famous nineteenth-century European theologians who had been influenced by liberalism and historical criticism. ${ }^{11}$ Al-Kayranāwī's arguments influenced the character of most subsequent Muslim polemical writings against Christianity. Muslim apologists often quoted from him at length, or at least employed the same methods. ${ }^{12}$

Western scholars of Islam and missionaries working during the period under discussion were keen on collecting Muslim anti-Christian polemical titles spread among Muslims. Steinschneider's 1877 article 'Polemische und apologetische Literatur in arabischer Sprache' was one of the first modern western collections of early Muslim polemical discussions and apologetics; it also examined some mediaeval and seventeenth-century texts. ${ }^{13}$ Steinschneider's work was meant to provide 'orientalists, historians of literature, theologians, and researchers of history, etc. with a bibliographical summary of Muslim polemical writings.' ${ }^{14}$ Arthur Jeffery (d. 1959), while serving as an Australian orientalist missionary at the School of Oriental Studies in Cairo, collected forty-five titles

8 Thomas Hartwell Horne. An Introduction to the Critical Study and Knowledge of the Holy Scripture (London: T. Cadell and W. Davies, 1818).

9 David Friedrich Strauss, Das Leben Jesu (Tübingen: C.S. Osiander, 1835).

10 Ann Avril Powell, 'Maulana Rahamat Allah Kairanawi and Muslim-Christian Controversy in India in the mid-19th Century', Journal of the Royal Asiatic Society 108 (1976): 42-63; Paul Eppler, Geschichte der Basler Mission 1815-1899 (Basel: Verlag der Missionsbuchhandlung, 1900); F. LaRoche, 'Karl Gottlieb Pfander', Evangelisches Missionsmagazin 6o (1917): 503-512; Arthur C.I.E. Mayhew, Christianity and the Government of India (London: Faber \& Gwyer, 1929); A.A. Powell, 'Muslim Reaction to Missionary Activity in Agra,' in Indian Society and the Beginning of Modernization: c. 1830-1850, ed. Cyril Henry Philips and M. Doreen Wainwright (London: School of Oriental and African Studies, 1976), 141-158: Christian W. Troll, 'Christian-Muslim Relations in India: A Critical Survey', Islamochristiana 5 (1979): 119-145: Schirrmacher, Mit den Waffen des Gegners, $103 \mathrm{ff}$.

11 Schirrmacher, 'The Influence of Higher Bible Criticism,' 273.

12 Umar Ryad, Islamic Reformism and Christianity: A Critical Reading of the Works of Muhammad Rashīd Rị̣̄a and His Associates (1898-1935) (Leiden: Brill, 2009).

13 Moritz Steinschneider, Moritz. Polemische Und Apologetische Literatur in Arabischer Sprache, Zwischen Muslimen, Christen Und Juden (Leipzig: F.A. Brockhaus, 1877).

14 Steinschneider, Polemische, 1. 
of anti-Christian books and pamphlets that were in actual use among Muslims in Egypt by $1925 \cdot{ }^{15} \mathrm{Jeffery}$ had been asked to make his collection in preparation for two missionary conferences, one in Hilwān (on the outskirts of Cairo) and the other in Jerusalem. His article reveals that the anti-Christian literature included both new writings and medieval Muslim-Christian controversial literature reprinted in modern editions. ${ }^{16}$ In another article, Jeffery states that the Muslim

apologetic literature of the old orthodoxy [at that time] is little more than a rehash of the old work of ... Ṭabarī, Ibn Ḥazm, and Ibn Taymiyya ...; but there is a new note of 'awakeness' to modern conditions in many of the pamphlets and tractates called forth by the ... work of Christian missionaries in Egypt, Syria, Turkey, or India. Some are urgent warnings to [Muslims] against Christian hospitals and schools, and against the circulation of Christian books. And some are replies to Christian books whose ... attack aroused Moslems to counter-attack. ${ }^{17}$

The present study examines a variety of Muslim polemical works in Egypt in the late nineteenth and early twentieth centuries that reflect how Muslims, both at the scholarly and the grassroots levels, perceived missionary work and missionary writings on Islam. These have been selected to highlight representative ideas that Muslims developed to respond to the Christian apologetics of western missionaries entering Muslim societies. These few examples will provide a brief and general perspective on the most important themes found in the polemics between Muslims and missionaries at that time.

15 Arthur Jeffery, 'A Collection of Anti-Christian Books and Pamphlets Found in Actual Use among the Mohammedans of Cairo', The Moslem World 15 (1925): 27-37.

16 Jeffery, 'A Collection'. This literature included Al-Ajwiba al-fäkhira of Ahmad Ibn Idrīs Al-Qarāfī, the Hidāyat al-hayāra min al-Yahūd wa al-Nașārā of Ibn Qayyim al-Jawziyya, and Al-Jawāb al-șaḥ̂h fì al-radd 'alä man baddala dīn al-Masīh of Ibn Taymiyya.

17 Arthur Jeffery, 'New Trends in Moslem Apologetics,' The Moslem World of Today, ed. John R. Mott, (London: Hodder and Stoughton, 1925), 305; Arthur Jeffery, 'Anti-Christian Literature', The Moslem World 17 (1927): 216-219; Arthur Jeffery, 'The Anti-Christian Moslem Press', The Moslem World 17 (1927): 428-430. Cf. Harry Gaylord Dorman, Towards Understanding Islam: Contemporary Apologetic of Islam and Missionary Policy (New York: Columbia University, Teachers College, Bureau of Publications, 1948); Summer 1914 Edition of the Descriptive Guide of the Nile Mission Press and Other Publications: Suitable for Work in Oriental Lands among Moslems, Jews and Christians, with a foreword by Arthur T. Upson (Cairo: The Nile Mission Press, 1914). On the Nile Mission, see E. Sanders, 'The Nile Mission Press', The Moslem World 34 (1944): 209-213. 
This investigation will show that Egyptian Muslim polemists deployed a variety of ad hoc arguments to withstand the polemics of the Christian missionaries. The Muslim writers drew upon various aspects of traditional Muslim polemics against Christianity, modern higher criticism of the Bible, and western studies of paganism and Eastern religions. They also attacked missionary motives as abusive and offensive. In their defensive strategies, the Muslim polemists tried to ward off Christian missionary attacks on the infallibility of the Qur'ān and the authenticity of the hadìth corpus and to attack Christian Christological doctrines ranging from the virgin birth and incarnation to the crucifixion and redemption.

\section{Infallibility of the Qur'ān}

\section{Quranic Testimony to the Truth of Christianity}

Missionary writings for Muslims frequently attempted to prove the genuineness of the Hebrew Bible and the New Testament in their current form on the basis of the Qurān itself. One well-circulated Christian missionary tract in Egypt dealing with this subject was Al-Burhān al-jalï 'alā șị̣hat al-Tawrāh wa al-Injül (The Glorious Proof for the Reliability of the Old and New Testaments), which provoked heavy reactions from Muslims. The tract was written by Revd Frederick Augustus Klein (d. 1903) of the Church Missionary Society (CMS) in Egypt between 1882 and 1893 to prove the reliability of the Christian Scriptures vis-à-vis the infallibility of the Qurān. The first editions of the Arabic version of the tract bear neither the author's name nor the name of the press where they were printed;18 they were probably firstly published by CMs in Jerusalem. ${ }^{19}$ The tract was used extensively by missionaries through the 1920s. $^{20}$

18 Jeffery, 'Press', 428.

19 Jeffery, 'Collection', 30; Descriptive Guide, 45. Al-Burhān was reprinted in 1899 by al-Muqtataf Press in Cairo; see http://www.coptic-university.com/index.php/resources/ books/get_book_by_ID/116\#,0 accessed 10 October 2014. About Klein, see Gerald H. Anderson, ed. Biographical Dictionary of Christian Missions (New York: Macmillan Reference USA), 370. Klein is also the author of The Religion of Islam (London: K. Paul, Trench, Trübner and Co., 1906). Maulana Muhammad Ali of the Ahmadiyya movement in India responded to the book under the same title: Maulana Muhammad Ali, The Religion of Islam (Lahore: The Ahmadiyya Anjuman Ishāaat Islam, 1990; originally published in 1936).

20 Jeffery, 'Collection', 30. 
The Christian argumentation in this book, which was common among missionaries at that time, works in two directions. First of all, it stresses the authenticity of the Bible on the basis of specific Quranic verses; and secondly it attempts to undermine the authenticity of Muslim traditions regarding the compilation of the Qurān and its transmission history as related in Muslim sources. In the spirit of this second strategy, Klein writes,

We wish 'our Muslim friends' had deeply examined their book [the Qur'ān] in order to become acquainted with the methods by which it was composed, collected, corrected and preserved; and to see whether the book they have nowadays is still the original: the same one which Muhammad and his companions had, or that it has become corrupted, changed and twisted. We see most of them [i.e. Muslims] do not pay attention to such significant matters, thinking that the Qurān was sent down to Muhammad; and Muhammad delivered it to his companions; and they delivered it to their followers, generation after generation, without the least of corruption or change. ${ }^{21}$

Continuing in the same vein, Klein quotes from al-Bukhārìs hadìth collection and al-Suyūtì's al-Itqān, a mediaeval manual of Quranic sciences, to argue that the Qur'ān in its present form is not complete. Also, he contends that errors, or at least variations, had crept into its text. Its existing arrangement was not that compiled during the lifetime of the Prophet Muhammad, and differences among the qurrä' (reciters of the Qurān) took place after the Prophet's death.

\section{AJournalist's Response}

Immediately after publication of al-Burḥān, Ḥasan Ḥusnī Pasha b. Ḥusayn 'Ārif al-Ṭuwayrānī (d. 1897), the proprietor of Al-Nìl Press and Al-Nìl newspaper, ${ }^{22}$ composed a pamphlet in refutation called Kitāb dalīl ahl al-īmān fì șihhat al-Qur'ān (A Book of Guidance for the People of the Faith to the Genuineness of the Qur'ān). The author's main motivation for writing his work was to refute the assaults of the above-mentioned tract on the Qur'ān, especially the missionary method of quoting from the Qurān itself to prove the genuineness of the

21 As quoted in Hasan Ḥusnī al-Ṭuwayrānī, Kitāb dalīl ahl al-īmān fì șịhhat al-Qur'ān (Cairo: Al-Nīl Press, 1309/1891), 3.

22 Hasan Husnī Pasha, Turkish by origin, was born in Cairo, and died in Constantinople. He published his Al-Nīl newspaper, which appeared at first daily on 17 December 1891 . Later it was published once a week. See Al-Ziriklī, Al-A'lām (Beirut: Dār al-'Ilm li-l-malāyīn, 1979), 2:187; cf. Martin Hartmann, The Arabic Press of Egypt (London: Luzac, 1899), 74. 
Christian Scriptures. Al-Tuwayrānī came across this anonymous missionary tract on Monday, 7 Ramadan 1309/1891 and finished writing his response a few days later on Friday, 9 Shawwāl 1309/1891. ${ }^{23}$ Al-Ṭuwayrānī's brief work is a selection of articles that he had previously printed in his newspaper Al-Nïl. Therefore, his ideas are not always well connected, and it is difficult to track down his information in the original sources.

In response to al-Burhān, al-Ṭuwayrānī emphasizes that it is an unconditionally justifiable right to defend one's own beliefs, but not in the fanatic tone of the missionary tract. ${ }^{24} \mathrm{He}$ is terribly unhappy with the fact that 'scientific researches, fair debates and controversies are turned into hostility rather than a method to reach the truth by examining and exchange of different ideas'.25 Al-Ṭuwayrānī bemoans the religious animosity between Judaism, Christianity and Islam, as well as the sectarian strife among Protestant, Catholic and Orthodox Christians, and Sunnī and Shīī Muslims. He is impressed by the European model of encouraging religious freedom, which led to a harvest of great civil rights for humanity. ${ }^{26}$

Al-Ṭwayrānī is taken aback by the deliberate anonymity of the author of the tract and the press where it was printed. For him, it is an indication that the writer completely lacked the courage to get involved in open and fair debate with Muslims. He accuses the missionary author of 'fanaticism' and 'hostility'. If the purpose of the missionary writer had been to study the Qur'ann truly within the realm of scholarly knowledge, he would have entered the 'arena' of debate with Muslims. But his ulterior motives were only to attack Islam. Al-Ṭuwayrānī then turns to speak about the ethics of foreign printing establishments in some detail. He argues that the government should oversee the publication of material of this nature and that it should take measures to prevent such publications, as they inflame different religious groups in the society. ${ }^{27}$

Al-Ṭuwayrānī does not elaborate any harsh counter-attacks on the Christian Scriptures. For him, to refute the beliefs of others is not a necessity. To his mind,

it is not our intention to counter the arguments with regard to the genuineness of the Torah, the Gospel or the Psalms, as discussing such

\footnotetext{
23 Al-Ṭuwayrānī, Kitāb. Jeffery, however, briefly discussed a reissue of the pamphlet which has no date; cf. Jeffery, 'Press', 428.

24 Al-Ṭuwayrānī, Kitāb, 6.

25 Al-Ṭuwayrānī, Kitāb, 6-10.

26 Al-Ṭuwayrānī, Kitāb, 6.

27 Al-Ṭuwayrānī, Kitāb.
} 
matters requires going beyond the objective of the study ...; it also necessitates wide knowledge of others' controversial books .... It is also known that such arguments would not lead any of the [debating] parties to follow or yield to the [religion] of the other .... Even the anonymous person hiding behind the tract cannot with his arguments convert any 'Muhammadan' [al-Țuwayrānì's own word] from his belief. The believers of any religion will always suspect any argument that an outsider might make against [their religion]. ${ }^{28}$

After giving an account of the nature of prophecy, the wonders of Prophets, and the Prophetic office in Islam, ${ }^{29}$ al-Ṭuwayrāni turns to the question of the corruption of the Qurān and argues that the early generations of Muslims neither distorted nor altered it and that the nature of the Qur'an itself is internal evidence for its divine origin. Al-Ṭuwayrānī insists,

Muslims themselves have never made any attempt to change the Qur'an as such. If we supposedly claim that those Companions were divided into two different factions, one with very strong religious zeal, which would have naturally defended it against any corruption of the text of the Word of God. If the other faction had no such purpose, but worldly objectives to overthrow the government, they would have exploited any change [of the primary source of Islam] as a pretext for thwarting the government and provoking Islamic sentiments. ${ }^{30}$

\section{An Azharite Student and a Civil Servant with the Railways}

Cairene Muslim responses to Klein's anonymously published missionary tract al-Burhān were not confined to the category of religious scholars only but included various other writers as well. The book Tanwìr al-adhhānfíal-radd 'alā mudda ì tahrîf al-Qur'ān (The Enlightenment of Minds: In Reply to Him Who Claimed There is Corruption in the Qur'an) ${ }^{31}$ by the then Azharī student 'Abduh Muhammad Zaki al-Dīn Sanad ${ }^{32}$ represents a more traditional response to the tract than that found in Al-Ṭuwayrānī.

\footnotetext{
28 Al-Ṭuwayrān̄i, Kitāb, 11.

29 Al-Ṭuwayrānī, Kitāb, 11-17.

30 Al-Ṭuwayrānī, Kitāb, 22.

31 'Abduh Muḥammad Zakī al-Dīn Sanad, Tanwìr al-adhhān fì al-radd 'alā muddà̃ taḥrīf al-Qur'ān (Cairo, 1310/1891).

$3^{2}$ Sanad, Tanwīr, 2 Sanad's work was later reprinted on the margin of another Muslim polemical work directed against the same missionary tract entitled Al-Sahm al-șaqül (The
} 
Zaki al-Dīn was not much concerned with criticizing or attacking the Bible, but he denigrates al-Burhān's method of proving the authenticity of the Bible with the help of Quranic statements. Additionally, he maintains that corruption could never have reached the Qurān and that the authenticity of the arrangement of the Quranic verses could not be doubted. According to the Tradition, Zakī al-Dīn says, the Prophet taught his Companions the arrangement of the verses and informed them of their places in every chapter (süra). The Prophet used to read the Qurān while his Companions were witnessing the reading. ${ }^{33}$ The same holds true for the arrangement of the chapters. According to Zakī al-Dīn, Muslim scholars are unanimous that the Qur'an is today found in the same arrangement as it had been during the Prophet's lifetime. ${ }^{34}$

Muhammad Ḥasan Farahāat, a civil servant with the Egypt Railway, wrote a similar work called Sahm al-lisān fì al-radd 'alā mudda' ì tahrî́f al-Qur'ān (The Dart of the Tongue in Reply to Him Who Claimed There is Corruption in the Qurān). ${ }^{35}$ In his booklet, Farahāt states that the missionary tract was not of any great value and that no scholar should take any effort to reply to it. Farahāt stressed that the goal of his writing was only to ridicule the way that missionaries spoke about Islam and the Qurān. ${ }^{36}$ The first two parts include the author's reply to the problem of the corruption of the Qurann, and his discussions on this point are to a great degree similar to those of Zaki al-Dīn. In the subsequent parts of the book, however, he turns to attack the Trinity and the divinity of Jesus, and the corruption of the Old and New Testaments.

\section{Al-Manär Responding}

The problem of missionaries trying to prove the genuineness of the Bible was still resonating in Egyptian Muslim circles into the early twentieth century. The well-known Salafì reformer Muhammad Rashīd Riḍā (d. 1935), the founder of the voluminous journal Al-Manār (Lighthouse), ${ }^{37}$ was annoyed by an article

Bright Sword) by Shaykh Bakr b. al-Sayyid 'Umar al-Tamīmī al-Dārī al-Ḥanafĩ al-Nabulsī (Cairo, 1895); see Jeffery, 'Literature', 30.

33 Sanad, Tanwìr, 11-15.

34 Sanad, Tanwīr, 14-18.

35 Muḥammad Ḥasan Farahāt, Sahm al-lisān fì al-radd 'alā muddaci tahrî̀f al-Qurāān (Cairo, 1311/1892).

36 Farahāă, Sahm, 3-4.

37 About Rịâ̄'s views on Christian missions, see for example, Charles C. Adams, Islam and Modernism in Egypt (London: Oxford University Press, 1933), 196ff.; Ayoub, 'Muslim Views', 49-70; Albert Hourani. Arabic Thought in the Liberal Age: 1789-1939 (London: Oxford University Press, 1962); Maurice Borrmans, 'Le commentaire du Manar à propos du 
published by a Muslim journalist in a 'big' newspaper, which agreed with missionary writings on the reliability of the Bible. The writer had even become doubtful about some Islamic teachings because of these arguments. Riḍa was surprised at how the journalist depended on Christian writings in this regard without reading Muslim works such as al-Kayranāwīs Izhār al-haqq. This Muslim journalist entertained doubts on the following three points: 1) the contradiction of Islamic sources with what is reported in Jewish and Christian Scriptures, 2) things reported in the Qur'an that are not mentioned in these Scriptures, and 3) the many reports in the Qur'an and the Sunna contradicting what is known in modern science. ${ }^{38}$

In reply, Riḍā advises this Muslim journalist, who was fond of reading Christian missionary works, to read western works on the Bible that prove its 'contradictions'. The Qur'an actually testifies that the Torah is a book of laws and precepts. It does not bear any testimony to the Bible now in hand, which is, according to these studies, nothing but a book of history borrowed from Assyrian and Chaldean mythologies contradicting the sciences of geology and archeology. Rather, the Qur'an bears witness merely to the Torah as a book of legislation (Q 5:44), which Moses, as well as the prophets of the Children of Israel and rabbis after him, had used in their rulings. Therefore, the Qur'an does not give any testimony to other Biblical historical books that had been written centuries after Moses by unknown authors. Urging this Muslim journalist not to be dazzled by such Christian assertions, Riḍa does not accept any historical analogy between the Qur'an and other Biblical books, such as Isaiah, Ezekiel or Daniel. As for the New Testament, which the Christian calls 'gospel', Riḍā says that it is in the view of Muslims a historical record that had been written down many years after Jesus' death. Additionally, it did not have strong

verset coranique sur l' amitié des Musulmans pour les Chrétiens $(5,82)$ ', Islamochristiana 1 (1975): 71-86; Olaf Schumann, Der Christus der Muslime: christologische Aspekte in der arabische-islamischen Literatur (Köln/Wien: Böhlau Verlag, 1988); Olaf Schumann, 'Arabische Schriftsteller begenen Christus', Hinaus aus der Festung: Beiträge zur Begegnung mit Menschen anderen Glaubens und anderer Kultur (Hamburg: E.B.-Verlag, 1997), 145-174; Schirrmacher, Mit den Waffen; Hugh Goddard, Muslim Perceptions of Christianity (London: Grey Seal Books, 1996), 55-58; Oddbjorn Leirvik, Images of Christ in Islam (Uppsala: Swedish Institute of Missionary Research, 1999), 140-143; Ryad, Islamic Reformism; Simon Wood, 'The Criticisms of Christians and the arguments of Islam: An annotated translation of Muhạmmad Rashīd Riḍās Shubuhāt al-Nașārā wā hujaj al-Islām;' (PhD thesis, Temple University, 2004), 95-96; the dissertation has been published as Christian Criticisms, Islamic Proofs: Rashïd Riḍ̄às Modernist Defense of Islam (Oxford: OneWorld, 2008).

See al-Manār 4.5 (May 1901): 179-183; cf. Ryad, Islamic Reformism, 178. 
asānìd (chains of transmission) proving its authenticity. The Qur'an had also testified that the Christians did not preserve all parts of the revelation about Jesus (Q 5:14). ${ }^{39}$

Riḍa contends that the Qurān also reproaches the Jews and the Christians for having mixed the real Bible with other historical stories. The Qur'an's request to the Christians to be judged in accordance with the Gospel (Q.5:47) does not mean that these Scriptures were not mixed with history. Thus, Riḍā argues, Muslims have no definitive criteria by which to distinguish these mixed parts from the original revelations. Additionally, there is no problem if Muslims consider the books of Exodus, Numbers, Deuteronomy and Leviticus as parts of the original Torah. The same holds true for Jesus' Sermon on the Mount (Matthew 5-7). In conclusion, Riḍa asks the writer to visit him in his office if his written answers are not sufficient. A month later, Ridā states that he had decided to stop writing about the matter since the writer had visited him and was persuaded by his answers. ${ }^{40}$

\section{The Qur'än Guarding the Christian Scriptures: A Question from Kuwait}

The missionary claim that the Qurān confirms the Bible also met resistance in other Muslim regions. For example, Yūsuf ibn 'Īsā al-Qinā'ì (d. 1973), the well-known Muslim educational reformer in Kuwait (a centre for the First Arabian Mission founded by Samuel Zwemer), ${ }^{41}$ became irritated by an Arabic edition of a missionary work under the title Al-Shahāda al-qur'āniyya ilā alkutub al-masihiyya (Quranic Testimony for the Christian Scriptures), which was written by the British politician and missionary to Bengal James Monro (d. 1920) and distributed among Muslims in the Gulf region. ${ }^{42}$ Therefore, alQinā̄ī approached the famous Muslim polemist Muṣtafā al-Rifāīi al-Labbān to request that he respond to Morno's book since some Muslims in Kuwait had

\footnotetext{
39 Ryad, Islamic Reformism, 179; Wood, 'The Criticisms', 95-96.

40 See al-Manār 4.5: 180; Ryad, Islamic Reformism, 179-180.

41 About the Arabian Mission, see for instance Lewis R. Scudder, The Arabian Mission's Story: In Search of Abraham's Other Son (Grand Rapids, MI: Wm. B. Eerdmans Publishing, 1998).

42 About James Monro's missionary activities, see Eugene Stock, The History of the Church Missionary Society, 4 vols. (London: Church Missionary Society, 1916), 4:234. Monro wrote Teaching of the Maulavis as to the Sinlessness of Muhammad, The Teaching of the Christian Scriptures on Sin and Salvation, and How does the Qur'an confirm and guard the Christian Scriptures? which were published by Christian Literature for India Society. Some of his tracts were also available in Urdu and Arabic.
} 
been 'deceived by it and deemed what the author wrote as true.43 Al-Labbān was a member of the Muslim Brothers in Egypt in the 1930s, and he is also known in Salafì circles for his anti-Christian writings.

Al-Labbān's response first assures his Kuwaiti correspondent that these 'misled' Muslims were lacking knowledge of their religion, the Qur'ân and its language. As for the Torah and the Gospel mentioned in the Qurān, they were totally different from the books and stories in the hands of the People of the Book nowadays. ${ }^{44}$ For al-Labbān, it is no surprise to see that the Christians who had 'corrupted' their Scriptures would attempt to 'cheat' concerning Islam, as it is their nature. For example, they attack Islam, saying that it was spread by force and the sword while forgetting that in the Old Testament the Children of Israel entered Jericho and utterly destroyed 'all that was in the city, both man and woman, young and old, and ox, and sheep, and donkey, with the edge of the sword' (Joshua 6:21). ${ }^{45}$ Against this, al-Labbān defends the concept of tolerance in Islam by noting how it protects the People of the Book. Once he was asked by a Christian whether Islam orders Muslim preachers in mosques to say, 'God, make the money of the Christians and their women booty for us'; al-Labbān takes this to be pure ignorance of Islam. ${ }^{46}$

Al-Labbān rejects Monro's argument that Islam confirms the Scriptures. Al-Labbān wonders which scripture, in the author's view, does the Qur'ān confirm, given that the Christian denominations themselves have disagreed on the forms, contents and versions of the Old and New Testaments. For al-Labbān, the authentic Bible does not exist. ${ }^{47} \mathrm{He}$ claims that the Gospel sent down to Jesus taught its followers compassion and mercy, whereas 'Christian nations nowadays are so cruel and harsh. The Gospel that should instill compassion in hearts does not exist; these nations became unbelievers as they do not follow it. ${ }^{4}$

Al-Labbān next strikes out against the police career of Monro, who was Assistant Commissioner (Crime) and Commissioner of Police of the Metropolis in London before his missionary service in India in $1890,{ }^{49}$ all of which disqual-

\footnotetext{
43 See Mustafā Aḥmad al-Rifāīal-Labbān, Mawāqifal-Islām min kutubal-Yahūd wa al-Nașārā (Cairo: Al-Mațba'a al-salafiyya, 1353/1934-1935), 3.

44 Al-Labbān, Mawāqif, 5-10.

45 Al-Labbān, Mawāaif, 11.

46 Al-Labbān, Mawāqif, 12.

47 Al-Labbān, Mawāqif, 13-14.

48 Al-Labbān, Mawāquif, 21.

49 See his name on the list of commissioners at: http://en.wikipedia.org/wiki/Commissioner _of_Police_of_the_Metropolis, accesed 10 October, 2014.
} 
ifies him from writing about religions and Islam in particular. 'It is a bold comment', Labbān writes sarcastically, 'of somebody known formerly as the police commissioner in London. Bolder than police commissioners are the military men who know nothing but swords, cannons and machine guns. How could police commissioners know anything about religions and researching them! ${ }^{50}$

\section{Authenticity of the Sunna}

Besides attacks against the Qurān, missionary writings cast doubt on the authenticity of the Sunna as well. Rashīd Ridā published two articles in 1916 under the title 'Sihhat al-Sunna' (The Reliability of the Sunna) ) $^{51}$ to refute an article written in Arabic in the same year by the above-mentioned Temple Gairdner in the missionary periodical Al-Sharq wa al-gharb (The Orient and Occident).

Gairdner's article was one of the routes through which Hungarian orientalist Ignaz Goldziher's work on hadith became known in Egypt. ${ }^{52}$ Some months after contributing to the Edinburgh World Missionary Conference (13-23 June 1910), Gairdner decided to take a Wanderjahr in Europe. The trip began in Germany in September 1910 where he spent 'three months [...] for the purpose of learning enough German to give [him] access to the incomparable German literature on Islamic subjects. 53 In his correspondence with Duncan Black Macdonald of the Hartford Theological Seminary in the United States, Gairdner states that 'it would have been worth learning German only for the sake of ... Goldziher's ... perfect gold-mine'.54

50 Al-Labbān, Mawāqif, 40-41.

51 Rashīd Riḍā, 'Al-Sunna wa șiḥhatuhā wa al-Sharī'a wa matānatuhā: radd 'alā du'āt alNașrāniyya bi Mișr' (two articles), Al-Manār 19 (June 30 \& July 15, 1916): 24-50 and 97-109. G.H.A. Juynboll, The Authenticity of the Tradition Literature: Discussions in Modern Egypt (Leiden: E.J. Brill, 1969), 3o; Ignaz Goldziher, Muhammedanische Studien, 2 vols. (Halle: Max Niemeyer, 1889-189o); English translation, Muslim Studies, trans. C.R. Barber and S.M. Stern, 2 vols. (London: Allen and Unwin, 1971). See also W.H.T. Gairdner, 'Mohammedan Tradition and Gospel Record: The Hadìth and the Injill, The Moslem World 5 (1915): 349-379.

53 Padwick, Temple Gairdner, $198 \mathrm{ff}$.

54 Padwick, Temple Gairdner, 204. For more details about his contact with Macdonald, see for example, J. Jermain Bodine, 'Magic Carpet to Islam: Duncan Black Macdonald and the Arabian Nights', The Muslim World 67 (January, 1977): 1-11. 
Gairdner expresses skepticism about the authenticity of almost all traditions ascribed to the Prophet. He maintains that the considerations that he followed would give ample ground for suspecting the stability of the foundations of Islamic traditions, and consequently of the enormous superstructure that had been erected thereupon. In his view, if the unreliability of traditions is established, the Islamic system ought logically to be discarded. His main concern, however, was to seek out similarities and differences between the authenticity of the transmission of both the hadith and the Gospels in order to reach his polemical conclusion: 'Thus Islam conducts us to a Book which truly was given forth by its founder. Christianity conducts us to a Christ who truly lived, wrought, taught, died, rose again on the third day and passed away alive into the Unseen.'55

Many Muslims were disturbed by Gairdner's ideas and urgently asked Riḍa to respond. Ridā berates missionary methods of investigating Muslim sources because they always raise questions about Islam not to reach the truth, but to cast doubt on others' beliefs. ${ }^{56}$ For Ridāa, each Muslim must believe in the authenticity of the Shari`a, which is only based on the hadith. The doctrines of Islam and the fundamentals of worship are supported by textual evidence from the Qur'an and the sound practical mutawätir traditions which have multiple chains of transmissions in early normative canons. Other issues in the Sharīa, such as mu'ämalät (transactions), are derived from the legal principles in the Quranic texts by using qiyās (analogical deduction) and mașlaha (public interest). Concerning the legal chapters on $\bar{a} d \bar{a} b$ and $a k h l a \bar{q}$ (good manners), Ridā admitted that there are precepts that are based only on $\bar{a} h \bar{a} d$ (isolated) traditions. These traditions should be considered as an extension and a commentary of the Qur'ān. To support his explanation, Riḍa quotes from the Qur'an: 'And We have sent down to thee the Message; that thou mayest make clear to mankind what is sent down to them; and that they may reflect' (Q 16:44). Riḍa links the word 'Message' (dhikr) to the Sunna by which the Qur'ān is clarified. ${ }^{57}$

Riḍa asserts against Gairdner that Muslims will never unanimously reject the Sunna nor the Sharīa in its entirety. Assuming only for the sake of argument that it might happen, Ridā maintains that people would definitely content themselves in the end with the Qurān and the sound 'amalì (practical) traditions, which have been transmitted through all generations up to the present time. ${ }^{58}$ Ridā concludes that if Gairdner's only purpose is to convert Muslims,

Gairdner, 'Tradition', 379.

Rị̣ā, 'Sunna', 26.

Riḍā, 'Sunna', 27-28.

Riḍā, 'Sunna', 28-30; cf. Juynboll, The Authenticity, 31-32. 
he should rest assured that most of those Muslims who might abandon Islam would never become real Christians; but rather turn into 'atheists' or 'antagonists'. They would convert to Christianity only out of poverty and need for missionary financial support, unlike western converts to Islam. ${ }^{59}$

\section{Muslim Christology}

Christology is one of the most contentious issues between Islam and Christianity. Late nineteenth and early twentieth century Egyptian Muslim writers are not reluctant to attack the beliefs of their missionary opponents by using Christology as a central point of departure in their polemics as well. For them, the doctrines of the Trinity and the divinity of Christ are simply the deification of a man. Other Christian doctrines are also portrayed as mythological absurdities, particularly the doctrines of original sin, atonement and salvation. As we have already mentioned, Muslim writers make use of the Biblical criticism that emerged in Europe in the nineteenth century as 'a new weapon of offence'60 against missionaries.

\section{The Gospel of Barnabas ${ }^{61}$}

One of the most important 'western' documents affecting Muslim polemics in the early twentieth century was the discovery of the Gospel of Barnabas and its 1907 publication in a bilingual Italian edition by Lonsdale and Laura Ragg. ${ }^{62}$ This medieval Gospel, which among other things denies the crucifixion of Christ, gained popularity in the Muslim world thanks to Rashīd Riḍa's Arabic edition published by al-Manār in 1908. The Arabic translation of this Gospel is actually a modern form of a long-enduring Islamic search for a Biblical witness that approves Islamic tenets. At Riḍā's request, the Arabic translation was made by his Lebanese Christian friend Khalīl Sa'̄ădeh (d. 1934).

Before Ridāa's publication of this Gospel into Arabic, he had championed the Russian author and philosopher Leo Tolstoy (d. 1910) and his attempt to write his own 'gospel', published in $1879 \cdot{ }^{63}$ Ridāa believed that Tolstoy's liberation from

\footnotetext{
59 Ryad, Islamic Reformism, 159-160.

6o Jeffery, 'Trends', 310.

61 This section is based on Ryad, Islamic Reformism, 213-241.

62 The Gospel of Barnabas, trans. Lonsdale and Laura Ragg (Oxford: Clarendon Press, 1907).

63 See David Patterson, ed. and trans., The Gospel according to Tolstoy (Tuscaloosa: The University of Alabama, 1992), xvii; Comte Léon Tolstoï, Les Évangiles, trans. T. de Wyzewa
} 
the dogmas of the Church actually brought him closer to the Quranic vantage point regarding the corruption of the Gospels. These views of Tolstoy were therefore substantial proofs for the truth of Islam.

In his introduction to the Gospel of Barnabas, Ridia sees the multiple versions of the Gospels as a result of the interest of each of Jesus' disciples in writing down a biography for his master including his sermons and history. Riḍa stresses the importance of non-canonical gospels in providing historical information about Christian conceptions that were not officially endorsed by Christian clergymen.

Although Riḍā's main interest in the Gospel of Barnabas emanated from the fact that it echoed the Quranic image of Jesus and his servanthood to God, he was not in 1908 actually concerned in his introduction to stress its historical authenticity. However, almost twenty years later, he sternly argues for its authenticity as 'superior to these four Gospels in its divine knowledge, glorification of the Creator, and knowledge of ethics, manners and values'.64 For Ridā, the Mosaic laws were derived from Hammurabi, and the ethics of the canonical Gospels emanated from Greek and Roman philosophy, but the Gospel of Barnabas came far closer to the truth.

Riḍā's edition provoked a Christian answer. A certain Iskandar Effendi 'Abd al-Masịh al-Bājūrī, an Egyptian Muslim convert to Christianity, a missionary in Giza and a follower of Temple Gairdner, reacted vehemently to Ridā’s publishing of this Gospel, which the latter had done only to satisfy his 'hidden fanatic hostility [...] boiling in his head' against Christianity and Paul. ${ }^{65}$ Bājūrī deems the 'fallacies' of this Gospel as harmful to Islam as well. Ridâ̄'s circulation of it might lead many Muslims, just like him, to convert to Christianity. He praised the translator Saādeh for his scientific introduction, while he berated Ridā’s introduction as 'immature' in its provocation against Christianity. In conclusion, Bājūrī belittles Rị̣ā's act as merely a 'weapon' that is directed against simple-minded Christians.

and G. Art (Paris: Librairie Académique Didier, 1896); Richard F. Gustafon. Leo Tolstoy: Resident and Stranger-A Study in Fiction and Theology (Princeton, NJ: Prin University Press, 1986); David Redston, 'Tolstoy and the Greek Gospel,' Journal of Russian Studies 54 (1988): 21-33. Cf. other works of Tolstoy on religions, A Criticism of Dogmatic Theology (1880-1883), What I Believe (1883-1884), and The Kingdom of God is Within You (1893).

64 Al-Manār, 9:245, as quoted in Ryad, Islamic Reformism, 235.

65 Iskander 'Abd al-Masīh al-Bājūrī, Khūdhat al-khalāṣ min sharak Injül Barnābāal-Frā Mārīñ al-qannāṣ (Cairo: Mațba'at al-Tawfĩq, 1908), 25. 


\section{Pagan Doctrines in Christianity 66}

A significant polemicist in Muhammad Rashīd Riḍā's circle was the Syrian Muḥammad Ṭāhir al-Tannīr (d. 1933), who was also familiar with western critical studies on the Bible. His Al-'Aqā̉id al-wathaniyya fi al-diyāna al-nașrāniyya (Pagan Doctrines in the Christian Religion) enjoyed wide popularity in Muslim circles in Egypt and elsewhere. ${ }^{67} \mathrm{Al}-\mathrm{al}$-Tannīr's father 'Abd al-Wahhāb made use of critical western theories of the Bible in his anti-missionary writings as well. ${ }^{68}$ Following in his father's footsteps, al-Tannīr published his treatise as a response to contemporary Christian apologetic and polemic literature on Islam. In his prelude, he sarcastically dedicates his work 'to the crusaders of the twentieth century, the missionaries'. ${ }^{69}$

In an attempt to prove the 'illogical' nature of the Christian faith, al-Tannir exploits a theory of 'pagan Christs' developed in several western sources such as Huxley, Jameson and Bunsen. ${ }^{70}$ One of al-Tannīr's reasons behind writing

66 This section is based on Ryad, Islamic Reformism, 57-59.

67 Muḥammad Ṭāhir al-Tannīr, Al-'Aqā̉id al-wathaniyya fi al-diyāna al-nașrāniyya (Beirut: n.p., circa 1912).

68 Jeffery, 'New Trends,' 310.

69 At the top of his list of missionary books, he mentions the journal The Moslem World which is, according to him, full of slander and broadsides against Islam. Among books in Arabic are al-Hidāya (The Guidance), 4 vols., (The American Mission, Egypt), found in the Descriptive Guide, 39; Al-Bākūra al-shahiyya (Sweet First-Fruits) (The Nile Mission Press), Descriptive Guide, Cat. No. 7; St. Clair Tisdall, Tanwīr al-afhām fì mașādir al-Islām, which is an Arabic version of Tisdall's The Original Sources of the Qur'ān (London: Society for Promoting Christian Knowledge, 1905): Misbāh al-hudā ilā sirr al-fidā (Torch of Guidance to the Mystery of Redemption) (The American Mission, Egypt), found in the Descriptive Guide, 41; Sir William Muir, Da'wat al-muslimīn ilā muțāla'at al-Kitāb al-Muqaddas althamin, (Invitation to Muslims to Read the Scriptures) (The American Mission, Egypt), found in the Descriptive Guide, 40. Among English works, he mentions M.A. Rice, Crusaders of the Twentieth Century (London, n. p., 1910); and Samuel Zwemer, Arabia: The Cradle of Islam (Edinburgh: Oliphant Anderson and Ferrier, 190o). On al-Tannī's book, see 'Book Reviews', The Moslem World 3 (1913): 197; this review was probably written by Gairdner, as it is signed with 'G'. See also the reaction of Louis Cheikho (d. 1927), the well-known Jesuit Father, Refutation of the falsification of Muhammad Tāhir al-Tannīr (Beirut, 1912), as quoted in G., 'Book Review'. See also Muhammad Țāhir al-Tannīr, 'Al-Radd al-matīn 'alā muftarayāt al-mubashshirīn (The Solid Reply to the Missionaries' Allegations)', Al-Manār 17.2 (January 26, 1914): 138-147; cf. Arthur T. Upson, 'A Glance at Al-Manār', The Moslem World 4 (1914): 394-395.

70 Thomas Henry Huxley, Evidence as to Man's Place in Nature (London: Williams and Norgate 1863); Mrs. Jameson and Lady Eastlake, The History of our Lord: as exemplified in Works of Arts (London: Longman, Green, Longman, Roberts, \& Green, 1892); Ernest De Bunsen, 
the book was to counter objections and attacks against Islam. Due to its harsh attacks, al-Tannīr's work was banned in Beirut. A second reason was his interest in calling on Christians to return to the 'truth' of Islam. The core of the book draws similarities between the story of Jesus and the stories of deities in other ancient religions. By these similarities, al-Tannir tries to prove that the Biblical story of Jesus is nothing more than a composite or rehash of ancient myths. For example, the Jesus story was compared to the Krishna story found in the Hindu Vedas, which date back at least to $1400 \mathrm{BCE}$, and the Horus myth, which was also said to be identical to the Biblical tale of Jesus. Al-Tannīr further argues for a wholesale influence of pagan mysteries found in ancient Egypt or India on Christianity. The Trinity, the idea of the cross, the incarnation, the virgin birth of Jesus, the appearance of the star in the East, and other events in the life of Jesus were all borrowed from heathenism. The same holds true for the doctrine of a suffering God who atones for the sins of men by his death; this was also traced in the oldest records such as those of Buddha and Krishna. Another significant aspect of al-Tannī's polemics was his analogy between the virgin birth and the myths of the birth of Krishna from the divine Vishnu into the womb of Devaki.

\section{Crucifixion and Redemption ${ }^{71}$}

Rashīd Riḍa and his followers made use of 'Pagan Christ' theories as well. In this regard, he composed his work Aqĩdat al-șalb wa al-fidā' (The Doctrine of Crucifixion and Redemption), in cooperation with his friend and student Muhammad Tawfíq Ṣidqī (d. 1922). ${ }^{72}$ In this work both authors employed such works as those of European mythicists J.M. Robertson (d. 1933) ${ }^{73}$ and Arthur Drews (d. 1935). ${ }^{74}$

As a medical student, Șidqī was able to read western works in English, and so he urges missionaries to save their religion from the critical questions raised

The Angel-messiah of Buddhists, Essenes and Christians (London: Longmans, Green, and Co., 1880); John Fiske, Myth and Myth Makers: Old Tales and Superstitions interpreted by Comparative Mythology (London: Trübner, 1873); James Fergusson, Tree and Serpent Worship (London: India Museum, 1873).

71 This section is based in part on Ryad, Islamic Reformism, 243-259.

72 Muhammad Rashīd Riḍā, 'Aqūdat al-ṣalb wa al-fidā' (Cairo: Maṭba'at al-Manār, 1353/19341935).

73 J.M. Robertson, Pagan Christs: Studies in Comparative Hierology, and ed. (London: Watts, 1911); J.M. Robertson, A Short History of Christianity (London: Watts, 1902); J.M. Robertson, Christianity and Mythology (London: Watts, 1900); J.M. Robertson. The Historical Jesus (London: Watts, 1916).

74 Arthur Drews, Die Christusmythe (The Christ Myth) (Jena: Diederichs, 1910-1911). 
by their fellow-citizens in Europe instead of travelling abroad to propagate Christianity outside Europe. As for the Quranic verse 4:157 denying that the Jews crucified Jesus, which was often interpreted to mean that the likeness of Jesus was put on another person, Șidqi compared these events to examples of illusions mentioned by European psychologists. For example, when a fire broke out in the Crystal Palace in London in 1866, people thought that an ape had tried to escape when in fact that had not happened.

With regard to the atonement, Riḍa argues that belief in this doctrine is not compatible with rational evidence and reason. The Maker of the universe should know all things. It is thus irrational to believe that God had been unaware that Adam would sin when He created him and then even abandoned Adam's children in sin until he created Jesus to salvage them. In other words, to believe in original sin implies that God was confused and did not know how to combine both His justice and mercy for mankind until He recognized thousands of years later that he should send Jesus to save mankind. ${ }^{75}$

What is mentioned in the Gospels about the crucifixion, Riḍa goes on, contradicts the belief that Jesus sacrificed himself for the sake of humanity. The Gospels signify that Jesus felt sorrowful and depressed at his impending death (Matthew 26:37-43). ${ }^{76}$ As for Jesus' death itself, Ridā rejects the view that Jesus was taken up from this world without dying. Instead he maintains that Jesus first died a natural death, and then he was taken up to heaven, though in soul only. Rị̂a places his rational objections against the dogma of redemption and satisfaction at the centre of his argument and explains how the Islamic way of salvation is far more sublime and logical than that of Christianity' 77

To elaborate his view of the God who dies and rises again, Riḍa quotes from al-Tannīr's above-mentioned work that this idea was associated with various pagan salvation cults, that originally there was nothing mystic about the death of Christ, but that later it was turned into a mystery by theologians who were acquainted with the old pagan mystery-religions. ${ }^{78}$ Riḍa tries to show that it was not Jesus who had died on the cross but someone else instead. Even some early Christian sects, according to him, did not believe that Christ had died-it was rather another person - and some modern European writers had evolved the same theory to explain the story of the resurrection. To support this opinion, Riḍa quotes from annotations in George Sale's translation of the Qurān:

Rị̣ā, 'Aqìdat, 18-19.

Rị̣ā, Aqīdat, 39-40.

Leirvik. Images of Christ, 141.

Riḍā, 'Aqīdat, 29-32; cf. Jeffery, 'Trends', 315-316. 
Several sects held the same opinion long before .... The Basilidians, in the very beginning of Christianity, denied that Christ himself suffered, but that Simon the Cyrenean was crucified in his place. The Cerinthians before them and the Carpocratians next ... did not believe the same thing that it was not himself, but one of his followers, very like him, that was crucified. ${ }^{79}$

\section{Conclusion}

To sum up, the modern Christian mission movement and the spread of its publications in the Muslim world was a major factor motivating a new generation of Muslims to compose apologetics against Christianity. The Muslim authors treated in this article took up the task of refuting books and tracts distributed by Protestant missionaries. ${ }^{80}$ It was not only Muslim religious scholars who wrote these polemics, but also journalists, as in the case of Tuwayrānī, and students and civil servants, as in the cases of Zakī al-Dīn Sanad and Farahāat.

The integrity of the Scriptures occupies the greatest space in the debate between the two sides, with the Qurān taking primary place. Nevertheless, the discussion extended to include the hadìth, as we saw with Ridā's reply to the article published in Al-Sharq wa al-gharb. Also, Muslims while defending the Qur'an as the Word of God often shifted to speaking about the corruption of the Christian scriptures and other Christian doctrines such as the Trinity, the person of Christ, redemption, etc. ${ }^{81}$ Put on the defensive, the Muslim authors understood the aim of the missionaries to be attacking Islam, and their resentment against missionary work led to counterattacks on Christianity.

The themes of controversy between the Muslim polemists and the missionaries followed the same patterns found in earlier Muslim-Christian polemical writings, including discussion of the Bible's reliability, the person of Jesus, etc. However, modern elements also appeared on both the Muslim and Christian sides. Muslim intellectuals, seeking any and all means to defend their beliefs against missionary polemics, read books written by western free-thinkers on historical criticism of the Bible and drew parallels between Christ and various pagan deities of antiquity to undermine the uniqueness and reliability of the Christian message. Similarly, the missionaries made use of western histor-

\footnotetext{
79 Rị̣ā, Aqìdat, 53; cf. George Sale, The Koran, new edition (London: W. Tegg, 1863) 1:55-56.

$80 \quad$ Dorman, Towards Understanding, 43 .

81 Jeffery, 'Trends', 311.
} 
ical scholarship on Islam. Missionaries transformed the critical scholarship of western Islamicists into attacks on Islamic norms, as in the case of Al-Sharq wa al-gharb's use of Goldziher's criticism of the hadith literature.

In a nutshell, Muslim polemists drew extensively on western Biblical criticism, but not exclusively so, and they were not hesitant to use whatever other arguments they found useful in counterattacking Christian doctrines. Muslim polemists had resort to works of western rationalists and atheists on the Bible, with which they attempted to show pagan elements in Christian belief about Christ. Yet, despite this familiarity with and use of western literature on Christianity, 'it seems that much material was borrowed from other Arabic sources rather than investigated afresh., ${ }^{2}$

82 Goddard, Muslim Perceptions, 94. 